\title{
Group status, geographic location, and the tone of media coverage: Jews and Muslims in New York Times and Guardian Headlines, 1985-2014
}

Hasher Nisar ${ }^{1,2^{*}}$ (D) and Erik Bleich ${ }^{3,4}$

* Correspondence: hasher.nisar@ gmail.com

${ }^{1}$ Present Address: University of Oxford, Oxford, UK

${ }^{2}$ St Antony's College, Oxford OX2 6JF, UK

Full list of author information is available at the end of the article

\begin{abstract}
Studies demonstrate that both group status and geographic location influence media coverage of immigrants, ethnic groups, and marginalized communities. We examine a systematic sample of headlines about Muslims and Jews from The New York Times and The Guardian between 1985 and 2014 to understand these two factors. We find that headlines about Jews have a more positive tone than those about Muslims, and that headlines about each group situated within the newspaper's country-such as American Jews or British Muslims - have a more positive tone than those set in the Middle East and North Africa (MENA) region — such as MENA Jews or MENA Muslims. These findings provide independent confirmation of prevailing research on group status and on the differences between coverage of domestic and foreign events. We expand this research agenda by intersecting these two strands of scholarship to examine the interaction between group status and geographic location, comparing the tone of headlines about lower-status domestic groups — such as Muslims in the United States or Great Britain — to that of the higher-status foreign group of Jews in the MENA region. We find that there is no meaningful difference between the portrayal of American Muslims and MENA Jews in The New York Times, but that Guardian headlines are significantly more positive toward British Muslims compared to MENA Jews. We explore these cross-national differences to show how the relationship between group status and geography is context specific.

Keywords: Muslims, Jews, Geography, Group status, Media tone, The New York Times, The Guardian, MENA, United States, Great Britain
\end{abstract}

In an era of resurgent anti-Semitism and rising social tensions around Islam, immigration, and ethnic identities (Blinder \& Richards, 2018; Cossé, 2019; Jones, 2019; Pew Research Center, 2011), it is increasingly important to understand how groups such as Jews and Muslims are covered in major media markets such as the United States and Great Britain, and what factors are associated with positive or negative coverage. This is especially true because media representations are a common way individuals learn about minorities within their national communities with whom they have little interpersonal contact. ${ }^{1}$ Moreover, research shows that the portrayal of social groups can influence individual attitudes toward them, as well as voting patterns and policy

${ }^{1}$ For more information, see Pew Research Center's 2007 report, Public Expresses Mixed Views of Islam, Mormonism: http://www.pewforum.org/2007/09/26/public-expresses-mixed-views-of-islam-mormonism/.

(c) The Author(s). 2019 Open Access This article is distributed under the terms of the Creative Commons Attribution 4.0 International License (http://creativecommons.org/licenses/by/4.0/), which permits unrestricted use, distribution, and reproduction in any medium, provided you give appropriate credit to the original author(s) and the source, provide a link to the Creative Commons license, and indicate if changes were made. 
preferences about minority-related issues (Boomgaarden \& Vliegenthart, 2007, 2009; Merolla, Ramakrishnan, \& Haynes, 2013; Saleem, Yang, \& Ramasubramanian, 2016).

To better understand the relationship between two key factors and media representations of immigrants and minorities, we assess the associations between group status, geographic location, and the tone of media coverage in two liberal democracies. In both the United States and Great Britain, ${ }^{2}$ surveys show that Jews as a group are viewed more positively than Muslims (Axt, Ebersole, \& Nosek, 2014; Parrillo \& Donoghue, 2005). Although there are few studies that directly compare coverage of these status groups in the media, those that exist suggest that the relative tone with respect to these groups parallels such differences (Bleich, Nisar, \& Vazquez, 2018). In addition, whether stories about a group are situated in a domestic or foreign geographic setting can affect the tone of coverage, given that reporting on foreign locations is more frequently oriented toward political violence (Nossek, 2004, p. 344). While the role of group status and geographic location have each been explored to some degree (D'Haenens \& Bink, 2007; Featherstone, Holohan, \& Poole, 2010; Ibrahim, 2010; Mertens, 2016; Powell, 2011), scholars have not yet investigated how they interact, and whether one factor is systematically more important than the other. We address this issue by comparing portrayals of Jews and Muslims in the domestic settings of the United States and Great Britain to portrayals of Jews and Muslims in the foreign setting of the Middle East and North Africa (MENA) through an analysis of a systematic sample of newspaper headlines from The New York Times and The Guardian over a 30-year time period.

By intersecting group status and geographic location through a cross-national, crossgroup, and cross-regional analysis, we can explore the relative impact of these factors in comparison to one another. Existing research on status and geography suggests that media coverage of higher-status domestic groups (such as Jews in the United States or Great Britain) will be more positive than that of lower-status foreign groups (such as Muslims in the MENA region). These are general propositions that we test on new data. Current scholarship offers no clear prediction, however, about the relative tone of coverage of higher-status foreign groups (such as MENA Jews) compared to lowerstatus domestic groups (such as American or British Muslims). If group status is a more powerful determinant, then coverage of Jews in the MENA region will be more positive than coverage of Muslims in the home country of the American or British outlet. If geographic setting is more influential, the reverse will be true. This leads to our key research questions: What is the relative tone of coverage of higher-status groups in a foreign setting compared to lower-status groups in a domestic setting; are these patterns consistent across countries; and what factors help account for crossnational differences? Perhaps the highest stakes in this investigation revolve around whether Muslim immigrants and their descendants are such a stigmatized group that even coverage of them 'at home' tends to be negative compared to coverage of Jews in the volatile MENA region.

We begin our analysis by examining the straightforward associations between status, geography, and media tone. Our first significant finding is that outcomes are consistent

\footnotetext{
${ }^{2}$ Further survey data for the United States are available from the American Faith Matters survey at the Association of Religion Data Archives (www.thearda.com). For Great Britain, survey data on views toward Jews and Muslims are available from 2010 National Centre for Social Research dataset (www.discover. ukdataservice.ac.uk) and the 2015 ICM Unlimited/Channel 4 survey (www.icmunlimited.com).
} 
with insights from existing scholarship: headlines from The New York Times and The Guardian about Jews have a significantly more positive tone than headlines about Muslims, and headlines about domestic groups (Jews and Muslims in the United States and Great Britain) are more positive than headlines about foreign groups (Jews and Muslims in the MENA region). We then examine the intersection of group status and geographic location. To do this, we focus on comparing the tone of coverage of Jews in the MENA context and Muslims in the domestic context. The aggregate data reveal that the tone of headlines about MENA Jews and domestic Muslims is statistically indistinguishable. In other words, in aggregate, group status and geographic location appear to be approximately equally associated with the tone of headlines about these groups.

While the relative tone of headlines about domestic Muslims and MENA Jews holds at the aggregate level, the story for the intermediary groups diverges when examining each country individually. There is no meaningful difference between the tone of headlines about MENA Jews and American Muslims in The New York Times; however, the tone of headlines about British Muslims is markedly higher than that of MENA Jews in The Guardian. We examine the themes prevalent in coverage of these groups in each newspaper to obtain a deeper understanding of the cross-national differences. Our results suggest that while it may be possible to derive general propositions about the associations between group status, geographic location, and the tone of coverage, it is equally important to investigate how those interactions play out within different national settings. In the end, our study shows that while Muslims may be associated with more negative stories than Jews overall, increasing coverage of stories about Muslims in a domestic setting-particularly as their demographic presence rises-may contribute to more positive portrayals of Muslims in the media.

\section{Case selection and contextual background}

We focus on gauging media tone about Muslims and Jews in the United States and Great Britain, as these countries offer several useful points of comparison. Both have significant immigrant and minority populations of Muslims and Jews that are prominent in public discourse. ${ }^{3}$ They also have similar media markets (Hallin \& Mancini, 2004, p. 198) with newspapers known for their international focus and reliable and factual information (Chalaby, 1996, pp. 304-306). Within each country, we identify a leftleaning, broadsheet newspaper for comparison: The New York Times in the United States and The Guardian in Great Britain. These newspapers are considered 'authoritative news media' sources and possess considerable social and political influence in their respective countries (Peterson, 2014, pp. 6-8). Each newspaper is also well-known for its commitment to advocating for the civil and human rights of immigrants and minorities (D’Harlingue, Joseph, \& Wong, 2008, p. 229; Poole, 2002, p. 56). These substantial similarities across country and newspaper type lead us to expect parallels in how Muslims and Jews are portrayed in these newspapers.

\footnotetext{
${ }^{3}$ According to the Pew Research Center, the population of Muslims in the United States was 3.45 million (1\%) in 2017 (www.pewresearch.org/fact-tank/2017/08/09/muslims-and-islam-key-findings-in-the-u-s-andaround-the-world/), the population of Jews in the United States was 5.7 million (1.8\%) in 2015 (www. pewresearch.org/fact-tank/2016/01/06/a-new-estimate-of-the-u-s-muslim-population/), the population of Muslims in the United Kingdom was 4.8 million (4.8\%) in 2010 (www.pewresearch.org/fact-tank/2016/07/1 9/5-facts-about-the-muslim-population-in-europe/), and the population of Jews in the United Kingdom was 280,000 (0.5\%) in 2010 (www.pewforum.org/2012/12/18/global-religious-landscape-jew/).
} 
We focus on the media tone about Muslims and Jews because they are socially significant groups in both countries, and because they have been the subject of prior research. There is an established academic discussion about the social position of Muslims in the West (Ahmed \& Matthes, 2016; Alsultany, 2012; Berkhout \& Ruedin, 2017; Poole, 2002; Richardson, 2004; Said, 1997); yet few studies engage this topic in a cross-country, cross-group, and cross-regional perspective. Like Muslims, Jews are prominent in public discussions about domestic and foreign issues and have been the subject of research within the context of the United States and Great Britain (Peterson, 2014; Shindler, 2007). In addition, the presence of Muslims and Jews in both the domestic context and in the MENA region allows for the type of comparison we seek to make about the relative importance of group status and geographic location.

Turning to our focus on group status, surveys have found that Jews are most often considered a higher-status group in the contemporary era in both countries, while Muslims are frequently considered a low-status group (Axt et al., 2014; Bleich et al., 2018; Parrillo \& Donoghue, 2005). Feeling thermometer studies in both countries confirm the pattern that the public has a more favorable view of Jews than Muslims. ${ }^{4}$ Media analysis has emerged to complement the conclusions drawn from studies and surveys on the relative standing of groups. Dozens of media studies reaffirm the broad negativity associated with Muslims in public discourse (Ahmed \& Matthes, 2016, p. 2). Scholarship on American and British media show that Muslims are portrayed negatively (Ahmed \& Matthes, 2016; D’Harlingue et al., 2008; Poole, 2002; Poole, 2016; Richardson, 2004). While there are few studies analyzing the media portrayals of Jews or comparing their portrayals to Muslims, two studies on the British media find that Jews are depicted more positively than Muslims (Bleich et al., 2018; Bleich et al., 2015). This leads us to our first hypothesis:

H1: Muslims will be associated with more negativity than Jews in both The New York Times and The Guardian.

We also gauge the impact of geographic location on media tone within and across ethno-religious groups. The framing of a group as 'ours' or 'theirs' influences the way in which journalists cover it. Foreign news coverage is often oriented toward political violence (Nossek, 2004, p. 344), having implications for the media portrayals of minorities that transcend national boundaries. While scholars have examined the relative standing of domestic and foreign populations within a single ethno-religious group (D’Haenens \& Bink, 2007; Featherstone et al., 2010, p. 183; Ibrahim, 2010; Powell, 2011), there is no comparable discussion about the coverage of domestic and foreign populations across multiple ethno-religious groups.

We examine the Middle East and North Africa (MENA) region because of its saliency in world politics and its large population of Jews and Muslims allowing comparison to those groups in the United States and Great Britain. As several media studies have

\footnotetext{
${ }^{4}$ The more favorable view of Jews than Muslims in the United States has been noted in the following feeling thermometer surveys: 2007 American Faith Matters Survey, 2011 American Faith Matters Survey, 2014 American Trends Panel Survey, and 2017 American Trends Panel Survey. The more favorable view of Jews than Muslims in Great Britain has been noted in the following studies and feeling thermometer surveys: The 26th British Social Attitudes Survey, the 2010 National Centre for Social Research dataset, and 2015 ICMUnlimited.
} 
shown, geographic location of coverage can affect portrayals of different groups. In the aftermath of 9/11, American Muslims were mostly depicted as 'patriotic' and 'peaceful' while foreign Muslims were portrayed as 'angry' and 'violent' (Ibrahim, 2010). Studies of British media, by contrast, provide a more nuanced picture. Mertens, for example, built on earlier research (Poole, 2002) and found that foreign stories about Muslims are not necessarily more violent than domestic stories about Muslims (Mertens, 2016, p. 149). Even though the portrayals of Muslims appear more complex in British media, British Muslims are often treated as "liberal, tolerant, peaceful' and 'good' in public discourse while the perpetrators of violent acts are associated with Al-Qaeda and categorized as 'bad (radical) Muslims' (Featherstone et al., 2010, p. 183). Although no systematic study has been undertaken to examine the coverage of domestic versus foreign Jews in the West, students of the British media noticed that negative coverage of Jews was often based on events abroad (Bleich et al., 2015, p. 956). Our second testable hypothesis is thus:

H2: Domestic populations of Muslims and Jews will be associated with more positivity in The New York Times and The Guardian than will their counterparts in the MENA region.

The existing literature thus provides concrete hypotheses about the association of group status and geographic location with coverage. Where those associations overlap in a congruent fashion, the predictions about coverage are clear (see Fig. 1). Current scholarship does not, however, provide clear hypotheses about the relative significance of these two factors in cases where the predicted associations point in opposite directions.

Given existing media studies and public opinion surveys about Jews and Muslims, we test the following hypotheses about the tone of coverage of domestic and foreign Jews and Muslims in The New York Times and The Guardian:

H3a: Domestic Jews will be associated with the most positive tone.

H3b: MENA Muslims will be associated with the most negative tone.

H3c: Domestic Muslims and MENA Jews will be associated with a tone that falls between that of domestic Jews and MENA Muslims.

For the groups in the intermediary position, however, there is no clear theoretical prediction about whether group status or geographic location will be more strongly associated with the tone of coverage, whether they will be equally associated with a positive or negative tone, or whether the outcomes will be highly variable by country. We explore this uncharted territory with a focus on three potential findings:

\begin{tabular}{lcc}
\hline & Domestic (US \& Britain) & Foreign (MENA) \\
\hline Higher Status (Jews) & $+/+$ & $+/-$ \\
Lower Status (Muslims) & $-/+$ & $-/-$ \\
\hline
\end{tabular}

Fig. 1 Predictions About Relative Tone of Coverage Based on Group Status and Geographic Setting 
1. If headlines about MENA Jews have a more positive tone than those about domestic Muslims, then group status appears more influential than geographic location in shaping and reflecting public perceptions about Jews and Muslims;

2. If headlines about domestic Muslims have a more positive tone than those about MENA Jews, then geographic location likely has a more significant influence than group status on public perceptions about Muslims and Jews; and

3. If headlines about domestic Muslims and MENA Jews have a similar tone, then group status and geographic location may have approximately equal significance in shaping public perceptions about Muslims and Jews.

Discerning the relative association between each variable and media tone has significant implications for our understanding of public attitudes toward immigrants and minorities. If group status plays a larger role, it helps to shed light on how stereotypic beliefs about minorities may be entrenched in modern liberal democracies. However, if geographic location has a stronger association, it suggests that increased coverage of minorities in domestic settings may alleviate their stigmatization as a group.

\section{Data and methods}

Our methodology builds on the coding system developed by Benson (2014) and closely follows that of Bleich et al. (2015), Bleich, Nisar, and Abdelhamid (2016), and Bleich et al., (2018). The main unit of analysis is the article headline. We chose the headline for analysis over the full-text of the article for several reasons. Existing research shows that headlines attract the attention of readers and serve as cognitive shortcuts (Andrew, 2007, pp. 28-31; Dor, 2003, pp. 697-699), especially given that the majority of readers scan headlines rather than read the article (Dor, 2003, pp. 718-720). The placement of headlines in newspapers stands out to the readers as they are usually the first or second element they view (Leckner, 2012, p. 169). The information that headlines convey to readers has a significant impact on how people understand the story and is independent from the impact of the full-text of the article (Ifantidou, 2009, p. 702). Readers who are frequent consumers of the media and are knowledgeable about the issue or group under discussion are more likely to read both the headline and the full text of the article and are less likely to be influenced by the tone of the story due to confirmation bias. Readers who are less engaged with the topic, on the other hand, are more likely to only read the headline and are more susceptible to being swayed by its tone. While focusing on the full text of the article has its own distinct advantages, headlines offer the opportunity to gauge perceptions toward groups and issues that are at the forefront of the public conscience and that reinforce and shape the attitudes of readers toward those groups and issues.

We used Lexis-Nexis to extract New York Times and Guardian ${ }^{5}$ headlines from 1 January 1985 to 31 December 2014 with the following root words: 'Muslim,' 'Moslem,' 'Islam,' 'Jew,' and 'Judai.' The selection of these terms leaves no ambiguity that their presence in the headline is directly related to the religion and group. Terms associated with each religion, such as their scriptures, holidays, and religious objects, were

${ }^{5}$ The Guardian is only published Monday through Saturday. 
Table 1 Distribution of Guardian and New York Times Headlines, 1985-2014

\begin{tabular}{llllll}
\hline & Final Dataset & & & Final Sample & \\
\cline { 2 - 3 } \cline { 5 - 6 } & Guardian & New York Times & & Guardian & New York Times \\
\hline Muslims & 4054 & 3966 & 506 & 497 \\
Jews & 1778 & 3603 & 222 & 451 \\
\hline
\end{tabular}

excluded because it may be the case that not all readers directly connect those terms with the group as a whole.

After removing duplicate and accidental headlines, ${ }^{6}$ we employed a systematic sampling technique to analyze every eighth headline in the final dataset. This technique ensured that the sample was representative of the overall distribution of headlines across time in each newspaper. Table 1 shows the total number of headlines in the final dataset and sample.

There are two main methods for coding media corpora: computer-assisted coding and human coding. Computer-assisted methods such as machine learning or lexical sentiment analysis techniques can reliably code large amounts of text. These methods, however, work best on corpora with a large number of words in each text. Due to the telegraphic nature of headlines and context-sensitive elements such as irony and metaphors, computer-assisted coding poses a challenge for the interpretive validity of headlines. We therefore undertook human coding to enhance the validity of our findings.

Using a codebook developed by the authors, each headline in the final sample was coded for its tone. Positive headlines portrayed the group as the object of discrimination or intolerance, or depicted the group as contributing to the political, economic, and social fabric of society. ${ }^{7}$ Headlines with a negative tone indicated that the group is dangerous or extreme, or reflected strong value differences from mainstream society. If a headline depicted the group in an unclear manner or in a simultaneously positive and negative light, then the headline was coded as having no tone. Table 2 provides examples for each type of tone.

To alleviate inter-coder reliability challenges posed by single-coded entries, two trained coders coded each headline. If the coders agreed, the code was retained. If the coders disagreed, the coding team discussed the difference. If an agreement could not quickly be reached, the headline was coded as having no tone. Because of this process, the dataset has a substantial number of headlines with no tone, yet this process also ensured the reliability and validity of headlines with a positive or negative tone. In addition, this method allowed the team to resolve any errors in the process that were the result of coder fatigue or data entry errors. ${ }^{8}$

\footnotetext{
${ }^{6}$ Accidental headlines contained the root word but were not related to the group, such as references to Yusuf Islam or Islamabad.

${ }^{7}$ Although some scholars have categorized the victim portrayal of a group as feeding into their negative image, as Benson (2014, p. 7) argues, headlines that portray the group as victim evoke sympathy toward the members and thus are better categorized as having a positive tone rather than a negative tone.

${ }^{8} \mathrm{We}$ also did a retrospective review of the intercoder reliability of our double-coded headlines. We used Krippendorff's alpha to measure the intercoder reliability for the tone variable. The calculation showed a value of 0.50. Our alpha falls below Krippendorff's (2004, p. 429) recommended alpha of 0.67 or higher. Our alpha, however, confirms the advantages of our coding method. Headlines are short and telegraphic. By having two coders code each headline and then reconciling any disagreements, we ensure the validity of the headlines with a positive, negative, and no tone.
} 
Table 2 Examples of Headlines with a Positive, Negative, or No Tone

\begin{tabular}{|c|c|c|}
\hline & New York Times Headlines & Guardian Headlines \\
\hline Positive & $\begin{array}{l}\text { - CUNY Professor Criticizes Jews } \\
\text { - To Allay Fears of Islam, Mosques Invite Visitors }\end{array}$ & $\begin{array}{l}\text { - Police investigate fire at Islamic community centre } \\
\text { in Muswell Hill } \\
\text { - Celebrating } 50 \text { Issues of Jewish Socialist Magazines }\end{array}$ \\
\hline Negative & $\begin{array}{l}\text { - Muslim Gave Racist Speech, Jackson says } \\
\text { - Appeals Court Upholds Terrorist Label for a Jewish } \\
\text { Group }\end{array}$ & $\begin{array}{l}\text { - Suspected Islamic terrorists arrested } \\
\text { - Tensions as Jewish settlers press demands in Hebron / } \\
\text { Israel and West Bank Politics }\end{array}$ \\
\hline No Tone & $\begin{array}{l}\text { - American Identity, Muslim Identity } \\
\text { - Muslims in America }\end{array}$ & $\begin{array}{l}\text { - G2: Women: This Muslim Life } \\
\text { - Cairo hits Islamic finance houses }\end{array}$ \\
\hline
\end{tabular}

The primary dependent variable of our study is the net tone of headlines for a group. In order to calculate the net tone of the coded headlines for a given group $(\mathrm{g})$ in a given country (c), the total number of positive-toned headlines was subtracted from the total number of negative-toned headlines and then divided by the total number of coded headlines. The formula below provides the tabulation of net tone:

Net Tone $(g, c)=\frac{\text { Headlines with Positive Tone }(g, c) \text {-Headlines with a Negative Tone }(g, c)}{\text { Total Number of Coded Headlines }(g, c)}$

The net tone for a given group in a given country can range from - 1 (100\% of the headlines with a negative tone) to 1 (100\% of headlines with a positive tone) with 0 indicating a neutral tone. For example, The Guardian consists of 222 coded headlines about Jews. Out of the 222 headlines, 116 headlines have a positive tone and 16 have a negative tone. The net tone for Jews in The Guardian is $[(116-16) / 222]=+0.45$. By calculating the net tone, we produce an index of the tone of headlines that allows us to directly compare the coverage of different groups across newspapers.

We examine two independent variables in this study: group status and the geographic location of each group in a given headline. The headlines were selected based on group identity; however, each headline in the final sample was also coded for its geographic location: domestic; MENA; or neither. ${ }^{9}$ If a New York Times headline focused on the group in the United States or a Guardian headline focused on the group in Great Britain, the headline was coded as 'domestic. ${ }^{\prime 10}$ If the headline was about the group in the MENA region, the headline was coded as 'MENA.' Additional file 1 includes more information about the countries that the MENA region comprises for this study. If the geographic location of the headline was ambiguous or not related to the countries under analysis, the headline was coded as 'neither.'

Using a codebook to identify the geographical location of headlines, the lead author conducted the geo-coding of all headlines in our final sample. Due to the simplicity of

\footnotetext{
${ }^{9} \mathrm{~A}$ few headlines could have been coded as both the domestic and MENA population of each group. However, they were coded for one population of the group depending on the focus and scope of the headlines. For example, 'Middle East crisis: British Jews: Beleaguered community torn by a distant war' or 'Islamic state: Britain Muslims fear backlash after Haines beheading.' Both headlines are connected to the Middle East, but they were coded as 'domestic' because the focus is on British Jews and Muslims.

${ }^{10}$ The headlines in our dataset sometimes included additional information such as the name of the author, date, and location of the story in the newspaper. If the newspaper headline was located in 'Metropolitan Desk,' 'National Desk,' 'New York Weekend' or other sections that signified a domestic setting, the headline was examined further and coded as 'domestic' unless the headline was not about the group in a domestic context. If the section was not included in the additional information, the headline was assessed to determine if it was clearly related to a domestic setting. An example of a headline would be 'Jewish School Plan Opposed.' The headline was coded as 'domestic' because if the headline was about a 'school plan' in a foreign country, the headline would have been more specific. In addition, the extra information states that the headline was located in the 'Long Island Weekly Desk' section, further confirming its 'domestic' setting.
} 
Table 3 Net Tone by Newspaper and Group

\begin{tabular}{|c|c|c|c|c|c|c|c|c|}
\hline \multirow[b]{3}{*}{ Tone } & \multicolumn{4}{|c|}{ New York Times } & \multicolumn{4}{|l|}{ Guardian } \\
\hline & \multicolumn{2}{|l|}{ Jews } & \multicolumn{2}{|l|}{ Muslims } & \multicolumn{2}{|l|}{ Jews } & \multicolumn{2}{|l|}{ Muslims } \\
\hline & Frame ct. & $\%$ & Frame ct. & $\%$ & Frame ct. & $\%$ & Frame ct. & $\%$ \\
\hline Positive & 213 & 47 & 116 & 23 & 116 & 52 & 164 & 32 \\
\hline Negative & 16 & 4 & 150 & 30 & 16 & 7 & 163 & 32 \\
\hline No Tone & 222 & 49 & 231 & 46 & 90 & 41 & 179 & 35 \\
\hline Net Tone & \multicolumn{2}{|c|}{+0.44} & \multicolumn{2}{|c|}{-0.07} & \multicolumn{2}{|c|}{+0.45} & \multicolumn{2}{|c|}{0} \\
\hline Total & 451 & & 497 & & 222 & & 506 & \\
\hline
\end{tabular}

the task, situating the group in an American setting in The New York Times, British setting in The Guardian, or MENA setting in both newspapers, we drew a random sample from the total set of headlines to be double-coded rather than having a second coder code the entire sample. Fifty coded headlines were selected for each group from each newspaper. Using CrowdFlower, a crowdsourcing platform for human intelligence tasks, headlines were uploaded as 'Data Categorization' tasks with instructions on the coding process. We used Krippendorff's alpha to measure our intercoder reliability to ensure the validity of single-coded entries. Krippendorff (2004, p. 429) states that the level of agreement should exceed 0.67 for researchers to draw 'tentative conclusions' from the data and 0.80 for the data to be 'similarly interpretable' by two or more coders. The overall alpha for our double-coded sub-sample was 0.83 , giving us high confidence in our geographic coding for all observations.

\section{Empirical findings: net tone comparing group status and geographic location}

We find that the individual associations of group status and geographic location with the overall net tone of each group are broadly consistent with insights from existing scholarship. Table 3 confirms H1. Jews are portrayed more positively than Muslims by a margin of +0.37 in The New York Times and +0.45 in The Guardian. The statistically significant differences in the net tone of headlines between both groups support the prevailing wisdom that Jews are depicted more favorably than Muslims in the United States and Great Britain. ${ }^{11}$

Table 4 confirms $\mathrm{H} 2$. In the aggregate, headlines about domestic groups (Jews and Muslims in the United States and Great Britain) have a more positive tone than headlines about foreign groups (Jews and Muslims in the Middle East and North Africa). Domestic Jews with a net tone of +0.41 and domestic Muslims with a net tone of +0.26 are covered more positively than their MENA counterparts with a net tone of +0.19 and -0.28 , respectively. The statistically significant differences in the net tone of headlines between the domestic and foreign groups provide further evidence that geographic context is meaningfully associated with the tone of coverage. ${ }^{12}$

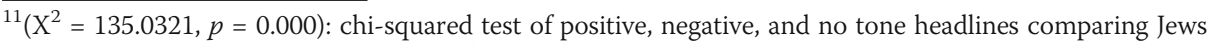
and Muslims in The New York Times; $\left(\mathrm{X}^{2}=56.1492, p=0.000\right)$ : chi-squared test of positive, negative, and no tone headlines comparing Jews and Muslims in The Guardian.

${ }^{12}\left(\mathrm{X}^{2}=71.8761, p=0.000\right)$ : chi-squared test of positive, negative, and no tone headlines comparing domestic Muslims and MENA Muslims in the aggregate; $\left(\mathrm{X}^{2}=13.1182, p=0.001\right)$ : chi-squared test of positive, negative, and no tone headlines comparing domestic Jews and MENA Jews in the aggregate.
} 
Table 4 Aggregate Net Tone - Domestic \& MENA

\begin{tabular}{|c|c|c|c|c|c|c|c|c|}
\hline \multirow[b]{2}{*}{ Tone } & \multicolumn{2}{|c|}{ Domestic Jews } & \multicolumn{2}{|c|}{ MENA Jews } & \multicolumn{2}{|c|}{ Domestic Muslims } & \multicolumn{2}{|c|}{ MENA Muslims } \\
\hline & Frame ct. & $\%$ & Frame ct. & $\%$ & Frame ct. & $\%$ & Frame ct. & $\%$ \\
\hline Positive & 111 & 46 & 39 & 34 & 122 & 41 & 36 & 14 \\
\hline Negative & 11 & 05 & 17 & 15 & 46 & 16 & 110 & 42 \\
\hline No Tone & 119 & 49 & 59 & 51 & 126 & 43 & 116 & 44 \\
\hline Net Tone & \multicolumn{2}{|c|}{+0.41} & \multicolumn{2}{|c|}{+0.19} & \multicolumn{2}{|c|}{+0.26} & \multicolumn{2}{|c|}{-0.28} \\
\hline Total & 241 & & 115 & & 294 & & 262 & \\
\hline
\end{tabular}

In addition to examining whether group status and geographic location are independently related to the tone of media coverage, we are also able to extend the boundaries of current scholarship by assessing the relationship between these two factors in comparison to one another. We do this by exploring the tone of coverage of four groups by intersecting the group status and geographic variables: Jews in the domestic context; Jews in the MENA context; Muslims in the domestic context; and Muslims in the MENA context. Existing research strongly implies that the tone of coverage of high-status domestic groups will be more positive than that of low-status foreign groups. Yet, the theoretical literature makes no strong predictions about the relative tone of coverage of the intermediary groups: high-status foreign groups (such as Jews in the MENA region) and low-status domestic groups (such as Muslims in domestic settings).

In the aggregate, $\mathrm{H} 3 \mathrm{a}$ and $\mathrm{H} 3 \mathrm{~b}$ are confirmed. We find that headlines about domestic Jews are associated with the most positive tone while headlines about MENA Muslims have the most negative tone. ${ }^{13}$ Table 5 replicates Fig. 1, but provides the actual net tone associated with the intersection of group status and geography in our aggregate data. H3c is also confirmed as domestic Muslims and MENA Jews occupy an intermediary position; however, statistical tests confirm that the difference in the net tone of headlines for both groups is indistinguishable. ${ }^{14}$ In other words, the aggregate data show that status and geography have an approximately equal association with the tone of headlines about these groups.

When analyzing the data by individual newspaper, we discover that the association of group status and geography with media tone varies in each national context. In The Guardian, geographic location has a stronger correlation than group status with media tone about Muslims and Jews. As shown in Table 6, the media tone about British Jews and MENA Muslims mirrors the pattern in the aggregate. ${ }^{15}$ While British Jews have the most positive tone and MENA Muslims the most negative tone, the story of the intermediary groups, British Muslims and MENA Jews, departs from the aggregate.

\footnotetext{
${ }^{13}$ The difference in headlines between both groups is statistically significant at the 0.01 level, $\left(\mathrm{X}^{2}=118.6336\right.$, $p=0.000$ ): chi-squared test of positive, negative, and no tone headlines comparing domestic Jews and MENA Muslims in the aggregate.

${ }^{14}\left(\mathrm{X}^{2}=2.5518, p=0.279\right)$ : chi-squared test of positive, negative, and no tone headlines comparing domestic Muslims and MENA Jews in the aggregate.

${ }^{15}$ The difference in the net tone of headlines is statistically significant at the 0.01 level, $\left(X^{2}=47.8794\right.$, $p=0.000)$ : chi-squared test of positive, negative, and no tone headlines comparing British Jews and MENA Muslims in The Guardian.
} 
Table 5 Relative Tone of Coverage Based on Group Status and Geographic Setting

\begin{tabular}{lll}
\hline & Domestic (US \& Britain) & Foreign (MENA) \\
\hline Higher Status (Jews) & +0.41 & +0.19 \\
Lower Status (Muslims) & +0.26 & -0.28 \\
\hline
\end{tabular}

As shown in Fig. 2, British Muslims have a more positive media tone than MENA Jews with the difference in the net tone of headlines between both groups being statistically significant. ${ }^{16}$ The relative media tone about the intermediary groups may challenge the common perception that British media portray Muslims more negatively than Jews, at least under all circumstances. The significance of geographic location outweighs the significance of group status and suggests that geography is more strongly associated with media tone about these groups in The Guardian.

The data from The New York Times, however, offer a different picture of the relationship between group status and geography. As shown in Table 7, headlines about MENA Muslims are the most negative, in keeping with the pattern found in both the aggregate and Guardian data. ${ }^{17}$ The media tone about American Jews, MENA Jews, and American Muslims, however, diverges from patterns found elsewhere. Unlike in The Guardian where British Jews and British Muslims had a more positive tone than MENA Jews, the difference in the net tone of New York Times headlines between American Jews and MENA Jews and between American Muslims and MENA Jews is statistically indistinguishable. ${ }^{18}$ Furthermore, even the difference in headlines between American Jews with a net tone of +0.38 and American Muslims with a net tone of +0.22 is not statistically significant at the $p<0.05$ level (although it is at the $p<0.10$ level). ${ }^{19}$

In The New York Times, it appears that group status carries more weight than it does in The Guardian, given that the net tone of MENA Jews is statistically indistinguishable from that of American Jews. In other words, the fact that the headline mentions Jews is

Table 6 Guardian Net Tone - Domestic \& Foreign

\begin{tabular}{|c|c|c|c|c|c|c|c|c|}
\hline \multirow[b]{2}{*}{ Tone } & \multicolumn{2}{|c|}{ British Jews } & \multicolumn{2}{|c|}{ MENA Jews } & \multicolumn{2}{|c|}{ British Muslims } & \multicolumn{2}{|c|}{ MENA Muslims } \\
\hline & Frame ct. & $\%$ & Frame ct. & $\%$ & Frame ct. & $\%$ & Frame ct. & $\%$ \\
\hline Positive & 34 & 53 & 12 & 26 & 84 & 47 & 21 & 15 \\
\hline Negative & 2 & 3 & 10 & 22 & 34 & 19 & 63 & 46 \\
\hline No Tone & 28 & 44 & 24 & 52 & 60 & 34 & 54 & 39 \\
\hline Net Tone & \multicolumn{2}{|c|}{+0.50} & \multicolumn{2}{|c|}{+0.04} & \multicolumn{2}{|c|}{+0.28} & \multicolumn{2}{|c|}{-0.30} \\
\hline Total & 64 & & 46 & & 178 & & 138 & \\
\hline
\end{tabular}

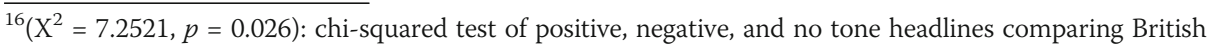
Muslims and MENA Jews in The Guardian.

${ }^{17}\left(\mathrm{X}^{2}=65.722, p=0.000\right)$ : chi-squared test of positive, negative, and no tone headlines comparing American Jews and MENA Muslims in The New York Times; $\left(\mathrm{X}^{2}=30.6362, p=0.000\right)$ : chi-squared test of positive, negative, and no tone headlines comparing American Muslims and MENA Muslims in The New York Times; $\left(\mathrm{X}^{2}=27.101, p=0.000\right)$ : chi-squared test of positive, negative, and no tone headlines comparing MENA Jews and MENA Muslims in The New York Times.

${ }^{18}\left(\mathrm{X}^{2}=2.1836, p=0.336\right)$ : chi-squared test of positive, negative, and no tone headlines comparing American Jews and MENA Jews in The New York Times; $\left(\mathrm{X}^{2}=0.8035, p=0.669\right)$ : chi-squared test of positive, negative, and no tone headlines comparing American Muslims and MENA Jews in The New York Times.

${ }^{19}\left(\mathrm{X}^{2}=5.1595, p=0.076\right)$ : chi-squared test of positive, negative, and no tone headlines comparing American Jews and American Muslims in The New York Times. The difference is therefore significant at the $p<0.10$ level.
} 


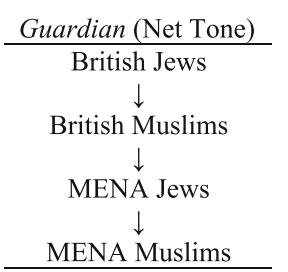

Fig. 2 Guardian (Net Tone)

more important than the geographic location of the story. At the same time, paralleling our findings for The Guardian, geography is also meaningful, as the tone of coverage of domestic Muslims approaches that for American Jews. In The New York Times case, a story about Muslims set within the United States is associated with positivity of that headline compared to stories about Muslims set in the MENA region, for which headlines are more likely to be negative.

\section{Empirical findings: examining prevalent themes of coverage}

The patterns show that group status and geography are each associated with the tone of coverage about Jews and Muslims in both newspapers. By intersecting these two factors, however, we find that the association of each variable with the tone of coverage about MENA Jews (a high-status foreign group) and domestic Muslims (a low-status domestic group) varies by newspaper. The findings raise two further questions: First, given the different relationships between group status, geography, and the tone of coverage about Jews in each newspaper, what accounts for the relatively more positive coverage of MENA Jews in The New York Times than in The Guardian? Second, given the importance of geography in media tone about Muslims, what accounts for the positive net tone of headlines about domestic Muslims across both newspapers? Lastly, what can help us understand the cross-national differences?

Before turning to these questions, however, it is important to briefly explore the consistent association of MENA Muslims (the low-status foreign group) with the most negative headlines and domestic Jews (the high-status domestic group) with the most positive headlines. Providing examples of typical coverage about these groups offers useful points of comparison for the groups in the intermediary position.

Negativity of headlines about MENA Muslims and positivity of headlines about domestic Jews

Looking at the two subgroups consistently at the ends of the spectrum, most headlines about MENA Muslims with a negative tone describe stories about Islamic extremism

Table 7 New York Times Net Tone - Domestic \& Foreign

\begin{tabular}{|c|c|c|c|c|c|c|c|c|}
\hline \multirow[b]{2}{*}{ Tone } & \multicolumn{2}{|c|}{ American Jews } & \multicolumn{2}{|c|}{ MENA Jews } & \multicolumn{2}{|c|}{ American Muslims } & \multicolumn{2}{|c|}{ MENA Muslims } \\
\hline & Frame ct. & $\%$ & Frame ct. & $\%$ & Frame ct. & $\%$ & Frame ct. & $\%$ \\
\hline Positive & 77 & 44 & 27 & 39 & 38 & 33 & 15 & 12 \\
\hline Negative & 9 & 5 & 7 & 10 & 12 & 10 & 47 & 38 \\
\hline No Tone & 91 & 51 & 35 & 51 & 66 & 57 & 62 & 50 \\
\hline Net Tone & \multicolumn{2}{|c|}{+0.38} & \multicolumn{2}{|c|}{+0.29} & \multicolumn{2}{|c|}{+0.22} & \multicolumn{2}{|c|}{-0.26} \\
\hline Total & \multicolumn{2}{|l|}{177} & \multicolumn{2}{|l|}{69} & \multicolumn{2}{|l|}{116} & \multicolumn{2}{|l|}{124} \\
\hline
\end{tabular}


and Muslim violence, such as 'Attack U.S., Qaeda Chief Tells Muslims in a speech' (The Guardian, 2013) and 'Algerian Islamic Extremists Launch Attack on Naval Base' (The New York Times, 1992). Only 15\% of Guardian headlines and 12\% of New York Times headlines about MENA Muslims have a positive tone, far lower than the proportion of headlines with a positive tone about MENA Jews (26\% and 39\%, respectively). At the opposite end of the spectrum, headlines about domestic Jews predominantly highlight instances of anti-Semitic acts, such as 'Vandals Deface Jewish Graves' (The Guardian, 1994), while another common theme features Jews as integrated members of society, such as 'Judaism's Alive and Well and Living in America; Rediscovered Tradition' (The New York Times, 1990). There are exceptionally few headlines that depict domestic Jews negatively. The percentage of negative headlines for domestic Jews stands at 5\% overall, compared to $16 \%$ of headlines about domestic Muslims.

\section{Net tone of MENA Jews in The Guardian and The New York Times}

The media tone about Jews demonstrates the varying role of group status and geography across both newspapers. In The Guardian, geography has a stronger association than group status with the tone of coverage about Jews. MENA Jews are portrayed more negatively than British Jews and British Muslims. The relatively negative net tone of headlines about MENA Jews is a function of an approximately equal number of positive and negative headlines. These headlines focus predominantly on the Arab-Israeli conflict. The positive headlines depict Jews as victims of the conflict, such as 'Iran Biggest Threat Since Nazis, Says Israel as Ahmadenijad Provokes New Outrage: Leader Calls for Jews to Be Sent to Europe: Threat to Quit Nuclear Pact Ahead of UN Report' (The Guardian, 2006), or as collaborators in solving the conflict, such as 'Holy Peaceniks: Secret Talks Between Jewish and Muslims Religious Leaders Might Just Succeed Where Politicians Have Failed' (The Guardian, 2001). The negative headlines, however, overwhelmingly highlight Jewish extremism and settlements, such as 'Jewish Terrorist Group Charged with Attacks Against Palestinians in the Occupied West Bank' (The Guardian, 1985) and 'Jewish Settlement Row Prompts Worldwide Anger' (The Guardian, 1996). In other words, the tone of headlines about MENA Jews is neither especially positive nor negative, but the overall balance shows a greater link between foreign headlines and negativity than exists in coverage of domestic groups. In this way, headlines about MENA Jews in The Guardian are somewhat more similar to those about MENA Muslims than they are to those about British Jews or British Muslims.

Unlike in The Guardian, group status is more strongly linked than geography to the net tone of headlines about Jews in The New York Times. There is a statistically indistinguishable difference in the net tone of headlines between American Jews and MENA Jews and between American Muslims and MENA Jews. Like domestic Jews across both newspapers, the relatively positive net tone of MENA Jews in The New York Times is a function of the prevalence of positive headlines. Most of the headlines about MENA Jews reference the Arab-Israeli conflict. While in some instances this coverage is negative, in others, headlines are positive because they portray MENA Jews as victims, such as 'Hebron Has a History of Jewish Expulsion' (The New York Times, 1988) and 'Abbas Condemns Killing of Jewish Family' (The New York Times, 2011). In other words, the tone of coverage 
about MENA Jews in The New York Times seems to be influenced by the fact that the emphasis of the coverage is on Jews as a vulnerable group within the MENA region.

\section{Positive net tone of headlines about domestic Muslims}

In both newspapers, it appears that the domestic setting of coverage about Muslims is related to media tone. This trend is clearly discernible in The Guardian. The more positive net tone of British Muslims than MENA Jews is due to a large number of positive headlines about British Muslims. When analyzing the 84 positive headlines from 1985 to 2014 in our dataset, several thematic patterns are visible. A plurality of the positively-toned headlines highlights anti-Islamic sentiment and anti-Muslim acts, such as 'Police Investigate Fire at Islamic Community Centre in Muswell Hill' (The Guardian, 2013), and the efforts of Muslims in fighting extremism and terrorism, such as 'Extremists' Actions at Odds with Islam, Says Warsi' (The Guardian, 2011). There are also a number of headlines that highlight the positive role of Muslim culture and institutions within Great Britain with headlines, such as 'Special Report: Muslim Britain: Culture of Charity' (The Guardian, 2002) and 'Muslim Council of Britain Says Female Genital Mutilation is "Un-Islamic"' (The Guardian, 2014). Furthermore, the frequency of positive headlines has increased over time, especially since the 9/11 and 7/7 attacks. 87\% of the positive headlines appeared after the $9 / 11$ attacks and $65 \%$ of them after the $7 / 7$ attacks. The greater number of positive headlines about British Muslims over time suggests that British Muslims are becoming increasingly visible within British society.

Unlike the straightforward story in The Guardian, portrayals of American Muslims in The New York Times are more complex. The statistically insignificant difference in the net tone of headlines between American Muslims and MENA Jews suggests that group status and geography are of approximately equal significance in understanding the tone of coverage about these groups. Yet, the difference in the net tone of headlines between American Muslims and MENA Muslims is statistically significant. This suggests that geography may play an important role in shifting the tone of headlines about American Muslims in a positive direction, just as it does in The Guardian.

Even though there are fewer positive headlines about American Muslims in The New York Times than about British Muslims in The Guardian, the themes are similar. The majority of positive headlines highlight anti-Islamic sentiment and anti-Muslim acts, such as 'Man Tied to Anti-Islam Film Denies Probation Charges' (The New York Times, 2012), and Muslims contributing to the fight against extremism and violence, such as 'Los Angeles Crowd Hears Islam Leader Ask End to Violence' (The New York Times, 2001). Furthermore, as in The Guardian, such headlines have become more prevalent over time, particularly since the $9 / 11$ attacks. $79 \%$ of the positive headlines appeared after the attacks. The domestic setting of coverage therefore appears to have developed and reinforced the positive media tone about British Muslims and American Muslims over time to the point that the geographic location of coverage is becoming increasingly important relative to the significance of group status.

\section{Understanding cross-national differences}

So far, we have explored our headline corpus to understand the types of headlines that drive the net tone of coverage of these groups. We have shown that while the primary 
hypotheses hold, there are interesting and important cross-national differences in how The New York Times and The Guardian cover intermediary groups. These results raise questions about the factors that influence the cross-national differences. Although our study was not specifically designed to answer these questions, we draw on our findings to explore elements that may help us understand how perceptions of these groups are constructed in different media outlets. Two factors in particular appear plausibly related to national variation in the distribution of net tone across our subgroups: the orientation of each newspaper on the Israeli-Palestinian conflict, and the demographic differences between the countries. We present each in turn as a starting point for future research.

The position of The New York Times as 'a newspaper of record' on the Middle East has been challenged with respect to the Israeli-Palestinian conflict. A 2002 study on the intifada finds that The New York Times was more likely to portray Israelis as victims and Palestinians as aggressors in headlines in comparison to The Chicago Tribune and The Washington Post, which had more even-handed coverage about both Israelis and Palestinians (Zelizer, Park, \& Gudelunas, 2002, pp. 295-296). The seemingly pro-Israeli leaning of The New York Times is consistent with our finding that the publication has paid more attention to the victimization of Jews across the MENA region and in the Israeli-Palestinian conflict in particular. By contrast, The Guardian is known not only for its pro-Palestinian orientation, but also for its liberal Jewish readership that believes in the right of self-determination for Palestinians (Shindler, 2007, p. 157). The orientation of each newspaper on the Israeli-Palestinian conflict may thus help account for the difference in the net tone of headlines about the foreign populations of Jews in both newspapers.

In addition, demographic differences may contribute to the divergent portrayal of the intermediary groups in both countries. According to the Pew Research Center, Muslims made up $4.8 \%$ of the United Kingdom population while Jews made up $0.5 \%$ of the population in $2010 .{ }^{20}$ Shindler $(2007$, p. 167) writes that The Guardian became 'a natural attraction and a sympathetic ear for many Muslim readers' as the Jewish community shrank and the Muslim community expanded. The larger Muslim population and readership may provide an incentive for The Guardian to cover more domestic stories about Muslims that highlight their contributions to society and the challenges they encounter on a daily basis. In the United States, Jews made up $1.8 \%$ of the population in 2015 while Muslims made up about $1 \%$ of the population in $2017 .{ }^{21}$ The smaller Muslim population in the United States may not provide as strong an incentive for The New York Times to cover stories about American Muslims that depict them in a variety of ways as being integral to the fabric of American society.

\section{Discussion and conclusion}

The factors that affect the tone of coverage about immigrants and other vulnerable minority groups-especially ones that transcend national boundaries-are intricately intertwined. As Gold (2006, pp. 961-962) argues, 'the increase of international migration and of diasporic communities, means that groups within specific national locations

\footnotetext{
${ }^{20}$ See footnote 3

${ }^{21}$ See footnote 3
} 
are increasingly influenced by depictions of race, status and group membership that are not fixed in geographic space.' Given that the media exert considerable influence over public perceptions and attitudes, it is vital to examine their role in constructing narratives about minority groups. The narratives that the media put forth not only impact social interactions and life opportunities, but can also affect voting behavior, policy preferences, and policy outcomes (Boomgaarden \& Vliegenthart, 2007, 2009; Merolla et al., 2013; Saleem et al., 2016). To move toward a society that seeks to alleviate the challenges facing vulnerable minority groups, we must closely examine how the media depict them, and what types of coverage are most likely to portray them in a positive or a negative light.

We contribute to this agenda by examining the tone of headlines about Muslims and Jews in The New York Times and The Guardian over a thirty-year period with a focus on two key variables: group status and geographic location. Our findings offer important independent evidence that supports the findings of scholarship linking group status and geography to the tone of media coverage. We also offer new insights into how these factors interact with one another in two different countries with respect to the tone of coverage about Muslims and Jews. Broadly speaking, we find that the weight of group status and geographic location are comparable, but that outcomes also depend on national context and on newspaper outlet. For example, while geography plays an important role in both newspapers, it has a stronger association with media coverage in The Guardian than in The New York Times, as headlines about both groups set in Britain are notably more positive than those about the same groups when set in the MENA region.

Media analysis in general and our method in particular offer new insights into understanding how groups are viewed within societies. At the same time, there are several limitations to our approach that can be addressed through future research. We analyzed two left-leaning, broadsheet newspapers with parallel characteristics. This strategy allows us to hold constant a number of elements that may affect the relationship between group status and geography in these newspapers. Future research can expand the analysis to a broader set of newspapers and to other countries to examine if the interaction between group status and geography is consistent across additional contexts. Researchers may also design studies aimed explicitly at identifying the factors that drive coverage across newspaper outlets. While our framework did not allow us to rigorously test all potentially relevant variables, two factors emerged that we believe warrant deeper investigation: the orientation of each newspaper on the Israeli-Palestinian conflict and demographic differences between each country. Further research can thus broaden our understanding of how group status and geographic location influence public perceptions of minority groups that transcend national boundaries.

Stepping back from the data, additional research can help identify the extent to which the distinction between domestic and foreign settings affects public perceptions. Existing studies show that individuals have a stronger reaction to negative news than positive news (Soroka, 2014, pp. 106-107). Readers of all of the headlines in our sample would have encountered marginally more negative headlines about Muslims than positive headlines. If negative headlines resonate more strongly with readers, the rise in positive headlines set in the domestic context may not be enough to offset prevailing negative public perceptions about Muslims. If this is the case, it may be especially 
important for newspapers concerned with providing balanced portrayals of vulnerable immigrant and minority groups to offset stereotypes by consciously increasing the number of positive stories. While this can be accomplished through coverage in any geographic location, it is easiest to envision newspapers ramping up the number of stories set in domestic locations, especially for immigrant Muslim populations that continue to grow in Western countries.

The media cannot immediately or permanently affect how the public views vulnerable populations, but news outlets play a meaningful role in portraying minorities in ways that can affect the prevalence of anti-Semitism, Islamophobia, and other types of discrimination. Accurately tracking and understanding the forces associated with the tone of articles about Jews, Muslims, and other identity groups can thus contribute to broader societal discussions about the forms and extent of racism and xenophobia in the United States, Great Britain, and beyond.

\section{Supplementary information}

Supplementary information accompanies this paper at https://doi.org/10.1186/s40878-019-0153-3.

Additional file 1. Scope of Middle East and North Africa.

Abbreviation

MENA: Middle East and North Africa

Acknowledgements

The authors thank Bertram Johnson for providing thoughtful comments on earlier versions of this article.

Authors' contributions

$\mathrm{HN}$ and EB are contributing authors in this article. Both authors read and approved the final manuscript.

Funding

The research was supported by the Kellogg Fellowship.

Availability of data and materials

The datasets analyzed during the current study are available from the corresponding author upon request.

Competing interests

The authors declare that they have no competing interests.

\section{Author details}

${ }^{1}$ Present Address: University of Oxford, Oxford, UK. ${ }^{2}$ St Antony's College, Oxford OX2 6JF, UK. ${ }^{3}$ Present Address: Middlebury College, Middlebury, USA. ${ }^{4}$ Department of Political Science, Middlebury College, Middlebury, VT 05753, USA.

Received: 4 October 2018 Accepted: 3 September 2019

\section{(2)}

\section{References}

Ahmed, S., \& Matthes, J. (2016). Media representation of Muslims and Islam from 2000 to 2015: A meta-analysis. International Communication Gazette, 79(3), 219-244. https://doi.org/10.1177/1748048516656305.

Alsultany, E. (2012). The Arabs and Muslims in the Media: Race and Representation After 9/11. New York: NYU Press.

Andrew, B. C. (2007). Media-generated shortcuts: Do newspaper headlines present another roadblock for low-information rationality? Harvard International Journal of Press/Politics, 12(2), 24-43. https://doi.org/10.1177/1081180X07299795.

Axt, J. R., Ebersole, C. R., \& Nosek, B. A. (2014). The rules of implicit evaluation by race, religion, and age. Psychological Science, 25(9), 1804-1815. https://doi.org/10.1177/0956797614543801.

Benson, R. (2014). Shaping Immigration News: A French-American Comparison. Cambridge: Cambridge University Press.

Berkhout, J., \& Ruedin, D. (2017). Why religion? Immigrant groups as objects of political claims on immigration and civic integration in Western Europe, 1995-2009. Acta Politica, 52(2), 156-178. https://doi.org/10.1057/ap.2016.1.

Bleich, E., Nisar, H., \& Abdelhamid, R. (2016). The effect of terrorist events on media portrayals of Islam and Muslims: Evidence from New York Times headlines, 1985-2013. Ethnic and Racial Studies, 39(7), 1109-1127. https://doi.org/10.1080/ 01419870.2015 .1103886

Bleich, E., Nisar, H., \& Vazquez, C. (2018). Investigating status hierarchies with media analysis: Muslims, Jews, and Catholics in The New York Times and The Guardian headlines, 1985-2014. International Journal of Comparative Sociology, 1-19. https://doi.org/10.1177/0020715218775142 
Bleich, E., Stonebraker, H., Nisar, H., \& Abdelhamid, R. (2015). Media portrayals of minorities: Muslims in British newspaper headlines, 2001-2012. Journal of Ethnic and Migration Studies, 41(6), 942-962. https://doi.org/10.1080/1369183X.2014.1002200.

Blinder, S., Richards, L. (2018). UK public opinion toward immigration: Overall attitudes and level of concern. Retrieved from https://migrationobservatory.ox.ac.uk/wp-content/uploads/2016/04/2019-Briefing-Public_Opinion_Immigration_ Attitudes_Concern.pdf.

Boomgaarden, H. G., \& Vliegenthart, R. (2007). Explaining the rise of anti-immigrant parties: The role of news media content. Electoral Studies, 26(2), 404-417. https://doi.org/10.1016/j.electstud.2006.10.018.

Boomgaarden, H. G., \& Vliegenthart, R. (2009). How news content influences anti-immigration attitudes: Germany, 1993-2005. European Journal of Political Research, 48(4), 516-542. https://doi.org/10.1111/j.1475-6765.2009.01831.x.

Chalaby, J. K. (1996). Journalism as an Anglo-American invention: A comparison of the development of French and Anglo-American journalism, 1830s-1920s. European Journal of Communication, 11(3), 303-326. https://doi.org/10.1177/0267323196011003002 .

Cossé, E. (2019, June 4). The Alarming Rise of Anti-Semitism in Europe. Retrieved from https://www.hrw.org/news/2019/06/04/ alarming-rise-anti-semitism-europe.

D'Haenens, L., \& Bink, S. (2007). Islam in the Dutch press: With special attention to the Algemeen Dagblad. Media, Culture \& Society, 29(1), 135-149. https://doi.org/10.1177/0163443706072002.

D'Harlingue, B., Joseph, S., \& Wong, A. (2008). Arab Americans and Muslim Americans in the New York Times, before and after 9/11. In N. Naber, \& A. Jamal (Eds.), Race and Arab Americans Before and After 9/11: From Invisible Citizens to Visible Subjects, (pp. 229-275). Syracuse: Syracuse University press.

Dor, D. (2003). On newspaper headlines as relevance optimizers. Journal of Pragmatics, 35(5), 695-721. https://doi.org/10. 1016/S0378-2166(02)00134-0

Featherstone, M., Holohan, S., \& Poole, E. (2010). Discourses of the war on terror: Constructions of the Islamic other after 7/7. International Journal of Media \& Cultural Politics, 6(2), 169-186. https://doi.org/10.1386/mcp.6.2.169_1.

Gold, S. J. (2006). From Jim Crow to racial hegemony: Evolving explanations of racial hierarchy. Ethnic and Racial Studies, 27(6), 951-968. https://doi.org/10.1080/0141987042000268549.

Hallin, D. C., \& Mancini, P. (2004). Comparing Media Systems: Three Models of Media and Politics. Cambridge: Cambridge University Press.

Ibrahim, D. (2010). The framing of Islam on network news following the September 11th attacks. International Communication Gazette, 72(1), 111-125. https://doi.org/10.1177/1748048509350342.

Ifantidou, E. (2009). Newspaper headlines and relevance: Ad hoc concepts in ad hoc contexts. Journal of Pragmatics, 41(4), 699-720. https://doi.org/10.1016/.jpragma.2008.10.016.

Jones, B. (2019, January 31). Majority of Americans continue to say immigrants strengthen the U.S. Retrieved July 1, 2019, from Pew Research Center website: https://www.pewresearch.org/fact-tank/2019/01/31/majority-of-americans-continueto-say-immigrants-strengthen-the-u-s/

Krippendorff, K. (2004). Reliability in content analysis. Human Communication Research, 30(3), 411-433. https://doi.org/10.1111/ j.1468-2958.2004.tb00738.x.

Leckner, S. (2012). Presentation factors affecting reading behaviour in readers of newspaper media: An eye-tracking perspective. Visual Communication, 11(2), 163-184. https://doi.org/10.1177/1470357211434029.

Merolla, J., Ramakrishnan, S. K., \& Haynes, C. (2013). "Illegal," "Undocumented," or "Unauthorized": Equivalency frames, issue frames, and public opinion on immigration. Perspectives on Politics, 11(3), 789-807. https://doi.org/10.1017/S1537592713002077.

Mertens, S. (2016). The representation of Muslims and Islam in the United Kingdom. In S. Mertens, \& H. De Smaele (Eds.), Representations of Islam in the News: A Cross-Cultural Analysis, (pp. 147-153). Lanham: Lexington Books.

Nossek, H. (2004). Our news and their news: The role of national identity in the coverage of foreign news. Journalism, 5(3), 343-368. https://doi.org/10.1177/1464884904044941.

Parrillo, V. N., \& Donoghue, C. (2005). Updating the Bogardus social distance studies: A new national survey. The Social Science Journal, 42(2), 257-271. https://doi.org/10.1016/j.soscij.2005.03.011.

Peterson, L. (2014). Palestine-Israel in the Print News Media: Contending Discourses. London \& New York: Routledge.

Pew Research Center (2007). Public Expressed Mixed Views of Islam, Mormonism. Benedict XVI Viewed Favorably But Faulted on Religious Outreach. Retrieved from https:/www.people-press.org/2007/09/25/public-expresses-mixed-views-of-islammormonism/.

Pew Research Center (2011). Muslim-Western Tensions Persist. Common Concerns About Islamic Extremism. Retrieved from https://www.pewresearch.org/global/2011/07/21/muslim-western-tensions-persist/.

Poole, E. (2002). Reporting Islam: Media Representations of British Muslims. London \& New York: I.B.Tauris.

Poole, E. (2016). The U.K.'s reporting of Islam and Muslims: Reviewing the field. In S. Mertens, \& H. De Smaele (Eds.), Representations of Islam in the News: A Cross-Cultural Analysis, (pp. 21-36). Lanham: Lexington Books.

Powell, K. A. (2011). Framing Islam: An analysis of U.S. media coverage of terrorism since 9/11. Communication Studies, 62(1), 90-112. https://doi.org/10.1080/10510974.2011.533599.

Richardson, J. E. (2004). (Mis)Representing Islam: The Racism and Rhetoric of British Broadsheet Newspapers. Amsterdam \& Philadelphia: John Benjamins Publishing Company.

Said, E. W. (1997). Covering Islam: How the Media and the Experts Determine How We See the Rest of the World (Revised Edition). New York: Vintage.

Saleem, M., Yang, G. S., \& Ramasubramanian, S. (2016). Reliance on direct and mediated contact and public policies supporting outgroup harm. Journal of Communication, 66(4), 604-624. https://doi.org/10.1111/jcom.12234.

Shindler, C. (2007). Reading the Guardian: Jews, Israel-Palestine and the origins of irritation. In D. Y. Egorova, Y. Egorova, \& T. Parfitt (Eds.), Jews, Muslims and Mass Media: Mediating the "Other", (pp. 157-177). London \& New York: Routledge.

Soroka, S. N. (2014). Negativity in Democratic Politics: Causes and Consequences. New York: Cambridge University Press.

Zelizer, B., Park, D., \& Gudelunas, D. (2002). How bias shapes the news challenging The New York Times' status as a newspaper of record on the Middle East. Journalism, 3(3), 283-307. https://doi.org/10.1177/146488490200300305.

\section{Publisher's Note}

Springer Nature remains neutral with regard to jurisdictional claims in published maps and institutional affiliations. 